IZA DP No. 5578

Is there Discriminatory Mortgage Pricing against Immigrants in the Spanish Lending Market?

Luis Diaz-Serrano

Josep M. Raya

March 2011 


\title{
Is there Discriminatory Mortgage Pricing against Immigrants in the Spanish Lending Market?
}

\author{
Luis Diaz-Serrano \\ Universitat Rovira i Virgili, CREIP \\ and IZA \\ Josep M. Raya \\ EUM, Universitat Pompeu Fabra \\ Discussion Paper No. 5578 \\ March 2011 \\ IZA \\ P.O. Box 7240 \\ 53072 Bonn \\ Germany \\ Phone: +49-228-3894-0 \\ Fax: +49-228-3894-180 \\ E-mail: iza@iza.org
}

Any opinions expressed here are those of the author(s) and not those of IZA. Research published in this series may include views on policy, but the institute itself takes no institutional policy positions.

The Institute for the Study of Labor (IZA) in Bonn is a local and virtual international research center and a place of communication between science, politics and business. IZA is an independent nonprofit organization supported by Deutsche Post Foundation. The center is associated with the University of Bonn and offers a stimulating research environment through its international network, workshops and conferences, data service, project support, research visits and doctoral program. IZA engages in (i) original and internationally competitive research in all fields of labor economics, (ii) development of policy concepts, and (iii) dissemination of research results and concepts to the interested public.

IZA Discussion Papers often represent preliminary work and are circulated to encourage discussion. Citation of such a paper should account for its provisional character. A revised version may be available directly from the author. 
IZA Discussion Paper No. 5578

March 2011

\section{ABSTRACT}

\section{Is there Discriminatory Mortgage Pricing against Immigrants in the Spanish Lending Market?*}

In this paper, we investigate whether evidence of discriminatory treatment against immigrants in the Spanish mortgage market exists. More specifically, we test whether, ceteris paribus, immigrant borrowers tend to be charged with higher interest rates on their mortgages than their Spanish born counterparts. To do so, we use a unique dataset on granted mortgages that contains information not only regarding the conditions of the loan but also the socioeconomic characteristics of the mortgagors. We observe that immigrants are systematically charged with higher interest rates. We apply the well known Oaxaca-Blinder decomposition to measure the extent to which this disparate treatment of lenders in mortgage pricing against immigrants is due to discrimination. Our results indicate that approximately two thirds of the gap in the interest rate between Spanish born and immigrant borrowers can be attributed to discriminatory treatment.

JEL Classification: R21, G21, J14

Keywords: immigration, discrimination, mortgage pricing, housing market

Corresponding author:

Luis Diaz-Serrano

Department of Economics

Universitat Rovira i Virgili

Av. de la Universitat, 1

43204 Reus

Spain

E-mail: luis.diaz@urv.cat

\footnotetext{
* The authors would like to acknowledge the financial support of the Spanish Ministry of Education (grant number SEJ2007-66318).
} 


\section{Introduction}

Discrimination against minorities has been an issue in the lending industry for decades. Consequently, mortgage lending has attracted the attention of politicians and researchers in recent years. US legislators have tried to protect minorities from discrimination in the mortgage and housing markets by means of certain statutes. ${ }^{1,2}$ Although the issue of discrimination against minorities has also attracted the attention of legislators in Europe, as yet there has been no legislation regarding the specific context of housing and lending markets. Neither Spain nor the rest of Europe has specific laws to protect minorities from discrimination in housing and lending markets. However, in Spain, the 2001 Immigration Law (art. 23) explicitly defines discrimination as the act of: "... imposing more expensive (tax/fee) conditions on foreigners than on Spaniards, or the act of refusing to facilitate goods or services to foreigners, just because they pertain to a specific race, religion, ethnicity or nationality". According to this article, unfair discretionary behaviour by Spanish lending institutions against immigrants is illegal.

Discrimination against minority borrowers can take many forms. A mortgage loan application can be turned down by a lending company on the grounds that the mortgagor belongs to an ethnic minority or holds immigrant status. Even if the loan application is accepted, mortgages for minority homebuyers can be priced at a higher interest rate. In this paper, we test for the first time the existence of discrimination outside the US in mortgage pricing against minorities. More specifically, using unusually rich Spanish data on accepted loans, we test: i) whether immigrants are

\footnotetext{
${ }^{1}$ These are the Fair Housing Act (1968), the Equal Credits Opportunity Act (1974), the Home Mortgage Disclosure Act (1975), the Community Reinvestment Act (1977) and the Financial Institutions Reform, Reregulation, and Enforcement Act (1989).

${ }^{2}$ See LaCour-Little (1999) for an overview of the key features of US federal housing legislation.
} 
systematically charged with larger interest rates on their mortgages, and; ii) if this disparate treatment exists, to what extent such treatment is due to market forces or to discrimination.

Our empirical test on discrimination in the Spanish mortgage market is straightforward and robust. The method we use allows us to test in a simple way whether identical borrowers with identical mortgages differing only in their minority status are subject to different interest rates on their mortgages. We control for a large set of household, mortgage and market characteristics, and use the well known OaxacaBlinder decomposition to decompose the gap in average mortgage interest rate between immigrant and native borrowers. ${ }^{3}$ Our results indicate that, on average, immigrants pay significantly larger annual interest rates than a native-Spanish equivalent borrower, and that between $2 / 3$ and $3 / 4$ of this gap can be attributed to discrimination.

The paper is structured as follows. In section two we describe the conceptual framework and overview the existing literature on discrimination in mortgage markets. Section three describes the empirical framework. In section four we describe the dataset. In section five, we carry out the econometric analysis. Finally, in section six we summarize and conclude.

\section{Conceptual framework and literature}

\subsection{Mortgage pricing in Spain}

In the US, most of the few papers testing for discrimination in mortgage pricing use the concept of overage. An overage is the difference between the price at which a loan closes and the minimum price acceptable to the lending institution as quoted on the

\footnotetext{
${ }^{3}$ See Oaxaca (1973) and Blinder (1973)
} 
lender's rate sheet. Overages exist because the reference interest rate is not necessarily the minimum price acceptable to the bank. In the Spanish mortgage market, the concept of overage as such does not exist. The nearest equivalent term is the annual differential interest rate (hereafter ADIR). The ADIR is defined as the amount that financial institutions add to the benchmark interest rate. In Spain, the most common benchmark interest rate is the EURIBOR, ${ }^{4}$ which is used for pricing almost $99 \%$ of mortgage loans. Although overages and ADIR seem to be identical concepts, Black et al. (2003) found that in their sample only $16 \%$ of the mortgages were charged an overage. In contrast, in our sample $95 \%$ of the homebuyers were charged the ADIR. Since the benchmark interest rate is fixed to all banks and determined by the European Central Bank, it is in the ADIR where discrimination may appear.

As in the case of overages, larger ADIRs may appear because of the behaviour of both borrowers and lenders. For the borrower, a lack of financial information, a severe liquidity constraint, risk aversion, or the unwillingness to pursue negotiations for a better deal could lead to a major differential. According to Spanish legislation, a mortgage operation is a civil contract; therefore, governing rules are based on the freedom of the contracting parties. Hence, Spanish mortgage legislation does not set upper bounds for differential interest rates. ${ }^{5}$ Despite this state of affairs, the Central Bank of Spain has a monitoring protocol whereby each lending institution has the obligation to report the maximum interest rate charged on any type of loan to the Central Bank. Thus, each institution sets its own maximum differentials which vary according to the loan type (mortgage, consumption loan, etc.) .

\footnotetext{
${ }^{4}$ The EURIBOR is the rate at which lending institutions borrow and lend to themselves in the European Union (EU). This interest rate is determined by the European Central Bank, therefore, it applies to the EU countries that use the Euro as currency and cannot be modified at a country level.

${ }^{5}$ The only limitation aimed at preventing abusive interest rates can be found in the Anti Usury Law 1908.
} 
In the Spanish housing market, the price of a mortgage also includes two other components in addition to the ADIR: the mortgage opening fee and the cancelation fee. The mortgage opening fee is a percentage of the total amount of the loan and is paid by borrowers to the lending institution in the moment when the mortgage contract is signed. The cancellation fee is the penalty that borrowers have to pay to the lending institution if they pay off the mortgage early, either partially or totally. These fees are also subject to discriminatory practices. Of these, the total cancellation fee is the only one for which the Central Bank of Spain sets a maximum rate. Interestingly, as we will see in the descriptive statistics, the total cancelation fee is the only component of the price of the mortgage for which we do not observe any differences between immigrants and natives.

\subsection{Theoretical models on discrimination}

Economic theory has determined different ways in which discrimination may arise. In the literature we can find two main theories. The first states that discrimination is driven by prejudices against a certain minority (Becker, 1971). In Becker's model agents without prejudices may also discriminate in response to the prejudice of others. The second theory is the model of statistical discrimination (Phelps, 1972), where unbiased individuals use race or ethnicity as a screening mechanism in a situation where there is asymmetric information. According to Becker's theory, individuals on the receiving end of discrimination pay for this through higher equilibrium prices, while minority outcomes are affected by statistical discrimination because lenders or firms use aggregated objective information regarding minorities. In the latter case, if part of the relevant information regarding particular individuals belonging to those minorities is 
unobserved, they are penalized because of their race or ethnicity. ${ }^{6}$ When discrimination occurs, it is not feasible to test whether it is prejudiced discrimination or statistical discrimination. The information needed to disentangle the nature of the discrimination in an economic transaction is generally unavailable. However, it seems clear that because of the characteristics of lending markets, it is unlikely to be prejudiced discrimination. We should not expect all or most loan officers to have personal prejudices against a certain minority, or that non-minority customers of a lending institution will move to a different one just because the institutions engages in economic transactions with minority customers. The equilibrium effects of statistical discrimination are expected to be different from those derived from prejudiced discrimination (Lundberg, 1991; Coate and Lowry, 1993). However, in our case we think that the type of discrimination is not relevant to the outcome because either way it will put discriminated borrowers in the same position.

It is economically rational for lenders to apply tighter credit restrictions if they are objectively sure that belonging to a specific group of borrowers is a significant indicator of repayment risk, and this risk cannot be fully observed by other characteristics of the borrower (Canner 1981; Stiglitz and Weiss 1981). However, although statistical discrimination in this situation seems reasonable, this behavior is still supposed to be illegal. There is conflicting empirical evidence as to whether minority borrowers are more likely to experience a mortgage default and therefore be more risk prone. Berkovec et al. (1994) observed that minority borrower default rates are higher and minority loans are less profitable. Berkovec et al. (1996) reached the same conclusion regarding black mortgagors in the US, while Freddie Mac showed that

\footnotetext{
${ }^{6}$ See Ross (2005) for an extensive overview.
} 
black and Hispanic borrowers have worse credit records than white borrowers. Anderson and Van der Hoff (1999) found that after controlling for differences in borrower and property characteristics, black households still had higher marginal default rates. These results contrast with those obtained by Mills and Lubuele (1994), who empirically proved that skilled minority households in the US performed equally as well as their non-minority counterparts with regard to loan repayment. Peter and Peter (2006) observed that immigrant borrowers are not more likely to experience a mortgage default than their native counterparts in Australia.

In Spain, raw statistics produced by the Central Bank of Spain based on aggregated data showed that in 2008, just after the burst of the housing bubble, $12.5 \%$ of non-Spanish born mortgagors became mortgage defaulters, while this only happened to about $1.6 \%$ of native Spanish mortgagors. ${ }^{7}$ This figure suggests that immigrants are riskier borrowers, and hence statistical discrimination seems justifiable for the sake of "business necessity". However, according to the 1991 Spanish Immigration Law (art 31), any form of discrimination, either prejudiced or statistical is illegal.

Some of the literature suggests that observed differences in outcomes between minority and non-minority individuals are attributable to non observed characteristics (Heckman and Siegelman, 1993). In such a situation, disentangling the role of discrimination in these differentials becomes a difficult task. The role of unobservable characteristics in economic outcomes is a well developed conceptual and empirical framework in labour economics. One paradigm of this area of research is the link between returns to schooling and unobserved heterogeneity due for example to differences in cognitive or non-cognitive skills, etc. There are at least two clear

\footnotetext{
${ }^{7}$ Report on Financial Stability (Bank of Spain, May 2009).
} 
extensions of this problem in context of our research. On the one hand, one could argue that mortgage pricing differentials may be attributed to potential unobserved differences in bargaining skills between minority and non-minority borrowers. On the other hand, another potential source of mortgage pricing differentials may arise because of asymmetries in the amount of information that both population groups possess; that is, better informed native borrowers may negotiate better mortgage conditions than immigrants. Unfortunately, suitable data for testing the effect of bargaining skills and information on differentials in loan conditions is not generally available. There is no doubt that unobserved factors may introduce some bias in our estimates; however, in our case, this problem is minimized because we control for a large set of individual and mortgage characteristics. For instance, we think the level of education is a good proxy to control both for bargaining skills and the level of information that a borrower may possess.

\subsection{Empirical evidence on discrimination in mortgage markets}

The literature regarding discrimination in mortgage markets can be divided into three big groups of studies. The first and most abundant group studies the effect of race/ethnicity on the probability that a loan application is turned down. ${ }^{8}$ The second group, also widely studied, focuses on "redlining"; that is, geographical discrimination against minority neighbourhoods. And the third group, which includes this paper, studies disparate treatment in mortgage pricing between minority and non-minority borrowers. Research in the latter area is remarkably scarce because data for this type of analysis is rarely available. All the empirical evidence regarding the three types of

\footnotetext{
${ }^{8}$ See Lacour-Little (1999) for an extensive overview.
} 
discrimination mentioned above contains two common features. First, all the studies are based on US data. Second, they are not unequivocal in their conclusions regarding the existence of discrimination.

The first attempts to study the relationship between mortgage lending and racial discrimination used rejection rates. Some econometric studies in the US used unpublished data on loan and individual characteristics and showed that in many of the metropolitan areas they investigated, race had modest statistical significance in explaining rejection rates when other legitimate financial characteristics were controlled for. Black et al, (1978), using HMDA data from New York, observed weak evidence that black borrowers had a larger probability of having a mortgage application rejected compared to white applicants, while Miller (1982) found that after controlling for credit history, the racial effect was not significant. In order to correct the bias in singleequation models, Maddala and Trost (1982) used a two-equation model but did not find evidence of racial discrimination. Rachlis and Yezer (1993) and Yezer et al (1994), reached the same conclusions as Maddala and Trost (1982). Horne (1997) analyzed Boston Fed data and concluded that there is no difference in approval rates between racial groups.

There are numerous other studies, however, that do find evidence of higher denial rates for minority borrowers. Using HDMA data, Canner and Smith (1991) found that black applicants were denied at least twice as frequently as white applicants of the same income and gender. Fix and Struyk (1993) also reached the same conclusion. However, the HMDA data do not contain enough variables to allow researchers to disentangle which part of this gap can be attributed to discrimination and which part to market forces. Munnell et al (1996) used HMDA data augmented with very rich data 
from 1991 regarding Boston-area banks, savings and loans companies, mortgage companies, and credit unions. They used three different measures of borrower credit history as regressors and found that the probability of having a mortgage application turned down was almost three times higher for black and Hispanic applicants than for their white counterparts. After controlling for a large set of borrower and market variables, they observed that minority applications were still $60 \%$ more likely to be denied. Using Boston Federal Study (BFS) data, Carr and Megbolugbe (1993) observed that race exerted a significant effect on mortgage application rejections.

Avery et al. (1994) found racial differences in the probability of rejection/approval and that these persisted for the different loan types, while Horne (1994) did not find evidence of discrimination. However, using information regarding lender credit standards, Horne (1997) observed that race effects were highly sensitive to model specification.

The empirical literature regarding redlining is also abundant, but again inconclusive. Ahlbrandt (1977), Bentston (1981) and Bentston and Horsky (1991) did not find evidence of redlining, while Hutchinson et al (1977), Bradbury et al. (1989), Hunter and Walker (1996) did. In a more recent study using Boston data, Tootell (1996) observed that once the effect of race and geography are disentangled, the evidence of redlining is weak. That is, discrimination is not against neighbourhoods but against the minorities living there. Using Houston data, Holmes and Horvitz (1994) did not find evidence that racial composition or changes in the racial composition of the neighbourhood affected the flow of mortgage credit. That is, there was no racially based mortgage redlining. 
Finally, as in the two other types of studies cited above that deal with the issue of discrimination, the literature regarding discrimination in mortgage pricing is again inconclusive. A descriptive analysis of the raw data coming from the 2004 and 2005 Home Mortgage Disclosure Act (HMDA) revealed that minority borrowers in the US are on average charged a substantially higher annual percentage rate on their mortgages than non-minority mortgagors. Boehm and Schlottmann (2007) found that black and Hispanic borrowers (particularly non-white Hispanics) are charged significantly higher interest rates than their white counterparts. However, in relation to overages, Courchane and Nickerson (1997) found differences according to race for both the size of overage and the likelihood of being charged an overage, although they concluded that no consistent pattern was evident and suggest that this disparate treatment was due to differences in the bargaining or negotiating power of whites and minorities. However, their data did not allow them to test this hypothesis. Black et al. (2001) studied overages from an area with a high Hispanic and African American population. They found that the yield spreads of Hispanic mortgagors are larger than those of whites; however, they did not find differences in overages between black and white applicants. Black et al (2003) controlled for numerous borrower and lender characteristics not available in previous studies and observed that minority mortgage borrowers who purchase homes pay larger overages than whites.

Courchane (2007) used data provided by lenders and used an endogenous switching regression model to estimate the determinants of the mortgage annual percentage rate (APR) conditional on whether minority and non-minority borrowers would be given either a subprime or prime mortgage. She observed that after controlling for individual and market characteristics, little of the APR gap between the two types of 
borrowers could be attributed to discriminatory treatment. Finally, Boehm and Schlottmann (2007) focus their study on examining the extent to which differences in the interest rates obtained by homeowners of different ethnicity and income levels can be explained by differences in characteristics of the borrowers, the property, and the loan itself. The results show that blacks and Hispanics (particularly non-white Hispanics) were charged with significantly higher interest rates than comparable white households. All these results taken together suggest that once relevant variables are controlled for, evidence of discrimination against minorities in mortgage markets emerges.

\section{Empirical framework}

Our empirical strategy consists of estimating reduced form linear equations on the determinants of the annual differential interest rates (ADIR). We estimate separate equations for immigrants and natives. Thus, our empirical model reads as follows:

$$
Y_{i t s}=\beta_{s}^{\prime} X_{i t s}+u_{t}+\varepsilon_{i t s}
$$

where the outcome $Y_{i t s}$ is the ADIR for individual $i$ at period $t$, and the subscript $s$ indicates whether the individual $i$ is immigrant $(\mathrm{s}=\mathrm{m})$ or native $(\mathrm{s}=\mathrm{n}), X_{i t s}$ is a set of individual and market (mortgage/property) characteristics, $u_{t}$ are time-specific effects, and $\varepsilon_{i t}$ is a random error term. It is important to remark that equation (1) is not a panel data model, but a set of cross-sections pooled throughout time. That is, individuals are observed only once throughout the sample period. 
With the estimated coefficients of model (1), we apply the conventional OaxacaBlinder decomposition method to decompose the gap between immigrants and natives in the outcome variable as follows:

$$
Y_{m}-Y_{n}=\left(\bar{X}_{m}-\bar{X}_{n}\right) \hat{\beta}_{n}+\bar{X}_{n}\left(\hat{\beta}_{m}-\hat{\beta}_{n}\right)
$$

where $Y$ is the outcome variable, as defined in equation (1), and the subscripts $m$ and $n$ refer to immigrants and natives, respectively. The left-hand side measures the estimated gap of $Y$ between both population groups. The first term of the right-hand side represents the part of the gap attributed to differences in observed individual and market characteristics (endowments), and the second term shows the part of the gap that is caused by lenders treating immigrants and natives differently (discrimination). ${ }^{9}$

\section{Data}

The dataset used in this paper refers to mortgages granted between 2004 and 2008. The data were collected each semester and pooled in a unique dataset. The data run from the first semester in 2004 to the first semester in 2008. Our sample is composed of roughly 49,000 observations, from which about 20,000 observations provide full information about all variables. These are the set of observations used in the econometric analysis. The data is provided by a mortgage brokerage company that mediates between homebuyers and banks. It is important to remark that borrowers do not deal directly with the financial institutions; therefore, the bargaining capacity of potential borrowers is somewhat limited. This company operates in a specific segment of the housing market, and its mortgage applicants generally acquire low-medium and

\footnotetext{
${ }^{9}$ The commonest application of the Oaxaca-Blinder decomposition is to measure wage gaps. Originally, the method was created to study the level of discrimination in gender wage gaps.
} 
medium rank dwellings. This means that our sample of mortgagors is quite homogeneous in terms of their socio-economic and dwelling characteristics. The dataset not only provides information regarding the conditions of the loan, but also a set of socioeconomic and demographic characteristics regarding the borrowers.

We distinguish six different population groups according to their birthplace: Spanish, Latin American, African, Eastern European, Asian and EU-15. ${ }^{10}$ In our sample, the frequency distribution of observations of birthplace that have reported a positive value in the mortgage and income variables is the following: 12,641 observations $(66.1 \%)$ correspond to Spanish born borrowers, 3,569 observations (18.7\%) correspond to Latin American borrowers and 1,347 observations (7\%) correspond to African borrowers. The rest of the sample is composed of 898 Eastern European born individuals (4.6\%), 376 Asians (2\%) and 281 EU15 born individuals $(1.5 \%)$. Given that we also carry out separate estimates according to birthplace, we exclude Asians and EU15 born individuals from the sample of immigrants, because they are not representative samples. In Table 1, we show a list of the variables used in this study and their definitions.

[Table 1, around here]

\subsection{The determinants of mortgage pricing}

The factors that determine the price of a mortgage can be divided into two main groups: market and demand. Market determinants are undoubtedly lead by movements in the interest rate over time. Depending on the direction of these movements, both lenders

\footnotetext{
${ }^{10}$ The EU-15 group comprises the fifteen EU countries before the 2004 EU enlargement, plus a set of rich non EU countries such as the US, Canada, Australia, Switzerland, Norway, etc...
} 
and borrowers may find their bargaining position strengthened. In our empirical model, we will control for this by including a set of time dummies, one per semester. We also include province dummies on the assumption that the mortgage broker will search for a loan in the same geographical area (province) as the one in which the dwelling is bought. Finally, the other relevant set of market factor variables concerns the characteristics of the mortgage. In our case, the dataset allows us to control for the repayment mortgage term, the size of the mortgage, and more importantly, for the loanto-value ratio. One interesting feature of our dataset is that it tells us which bank grants each mortgage to each borrower. We think this is better than having data from a single lending institution. This information makes it possible to include bank fixed-effects in our empirical model and thus to control for the fact that some lenders may have more market power than others, and hence more bargaining power.

The second group of variables deals with the demand factors and is mainly composed of the set of borrower characteristics. The first important factor to be considered is bargaining skills, which are usually an unobservable trait of the individual. However, as we mention in the previous section, we use the education level as proxy in place of bargaining skills. We expect more educated individuals to possess better bargaining skills than less educated individuals. Lower language skills is also a potential handicap for immigrants when they bargain the conditions of their mortgages. In Spain, the largest immigrant community is the Latin American community, whose members use Spanish as their mother tongue. We can expect Spanish speakers to exhibit better negotiating skills than those who come from non-Spanish speaking countries. Thus, in addition to education, we consider the place of birth of the immigrant (Latin America, Africa or Eastern Europe) as an additional proxy of 
bargaining skills. We also include a set of borrower's socio-demographic characteristics, i.e. age, marital status, type of labour contract, household income and occupation.

\subsection{Descriptive statistics}

In Table 2 we show descriptive statistics of the variables used in our analysis divided according to place of birth of the mortgagor. Raw comparisons of the summary statistics in Table 2 show that, on average, Latin American, African and Eastern European borrowers are charged with a substantially larger ADIR than Spanish born mortgagors. For Spaniards, the ADIR added to the benchmark annual rate is about 0.84 percentage points, while for Latin Americans, Africans and Eastern Europeans the ADIR is 1.04\%, $1.02 \%$ and $1.06 \%$ percentage points, respectively. A comparison of the average values for opening commissions reveals a similar state of affairs; Latin Americans (1.083\%) and Africans (1.154\%) are, on average, charged with higher opening commissions than Spanish born mortgagors (1.044\%). However, no differences are observed regarding Eastern Europeans (1.046\%).

The descriptive statistics reported in Table 2 also show some interesting patterns. Debt-to-income and loan-to-value ratios reveal quite significant differences between Spanish borrowers and the other immigrant population groups. It is quite striking that the mortgages granted to Spaniards are significantly more conservative in terms of risk than for immigrant borrowers. For instance, for Spanish mortgagors, the average loan-to-value ratio is $81.5 \%$, while for African and Latin American borrowers these ratios are 87.7 to $90.7 \%$, respectively. Debt-to-income ratios are also significantly 
smaller for Spanish borrowers $(56.1 \%)$, whereas these ratios are $75.3 \%$ for Latin Americans, $61.6 \%$ for Africans, and $66.2 \%$ for Eastern Europeans.

The data also reveal socio-demographic differences between Spanish and immigrant borrowers: on average immigrant borrowers are less educated and are employed in less qualified jobs. However, we do not observe remarkable differentials regarding income among population groups. Spanish mortgagors report an average monthly income of $1447 €$, while Latin American, African and Eastern European borrowers report an average monthly income of 1398, 1331 and $1455 €$, respectively. Another key variable that determines the potential risk is the borrower's type of labour contract. Our data reveal that with the exception of African borrowers (37.7\%), the share of mortgagors with an indefinite contract is similar across population groups; that is, $57.3 \%$ for Spaniards, $52.5 \%$ for Latin Americans and 51.4\% for Eastern Europeans. These statistics suggest that immigrant mortgagors do not report significantly worse economic conditions than Spanish born borrowers.

In Table 3, we report the results of the tests of the mean differences in the ADIR between Spanish born and immigrant borrowers. We observe that mean differences in the ADIR between natives and each immigrant group are highly statistically significant. These differences are $0.22,0.21$ and 0.18 percentage points for Eastern European, Latin American and African borrowers, respectively. The mean difference between Spanish born borrowers and the three groups of immigrants taken together is 0.2.

[Table 2, around here]

[Table 3, around here] 
Tables 4 and 5 show the results of the tests of mean differences in the ADIR between natives and immigrant borrowers according to city and bank, respectively. In Table 4, we report the tests for cities with a representative sample of individuals. In all the selected cities, average differentials between immigrants and natives in the ADIR have turned out to be statistically significant. This result suggests that there is no geographical pattern to disparate mortgage pricing. However, there are substantial differences across cities, since these differentials range from 0.086 and 0.111 percentage points in Seville and Cordoba to 0.482 and 0.364 percentage points in Valladolid and Huelva, respectively. It is worth noting the fact that the between-cities standard deviation in the ADIR is 0.09 for natives and 0.16 for immigrants, which suggests that across geographical areas the treatment of natives is more homogeneous than the treatment of immigrant borrowers.

In Table 5 we report the tests on mean differences in the ADIR between Spanish and non-Spanish born mortgagors across banks. As before, we only report the results concerning those banks with a representative sample of homebuyers. In only two out of the fourteen banks reported in Table 5 are immigrants not charged higher ADIRs than natives (branches $\mathrm{B}$ and $\mathrm{Q}$ ). In the remaining twelve banks, we observe statistically significant differences in ADIRs in favour of native borrowers. In those banks where differentials in the ADIR are statistically significant, these differentials range from 0.084 in bank $\mathrm{G}$ to 0.577 in bank $\mathrm{C}$.

[Table 4, around here]

[Table 5, around here] 


\section{Econometric results}

\subsection{The determinants of mortgage pricing}

Final estimates are based on a sample of 18,710 individuals, of whom about $66 \%$ are Spanish born and the remaining $34 \%$ are immigrant borrowers, more specifically Latin American, African and Eastern European. Table 6 reports the results of the OLS estimation of equation (1) for the full sample of borrowers, i.e. Spanish and immigrants together. In Model 1, we estimate equation 1 including three dummies for immigrant birthplace: that is, Latin American, African and Eastern European. Birth place dummies have turned out to be positive and highly statistically significant. Our results indicate that after controlling for the large set of demand and supply variables, Latin American mortgagors are, ceteris paribus, charged $0.146 \%$ more than their Spanish born counterparts. These differentials are $0.136 \%$ and $0.140 \%$ for African and Eastern European borrowers, respectively. These results also indicate that there are no differences in the ADIR across different immigration groups.

Econometric estimates provided by Model 1 reveal that most of the variables behave accordingly. Regarding the loan characteristics included in the empirical model, we observe the expected positive sign for loan-to-value, mortgage term and loan amount, since higher values for these variables increase the loan risk. Furthermore, borrower characteristics also behave according to expectations. Education significantly reduces the ADIR charged on the mortgage. This is not only because better educated individuals theoretically possess a higher income generating capacity, but also because they are more likely to have better bargaining skills. Mortgagors with worse contractual conditions in their jobs are charged significantly higher ADIRs because they are regarded as riskier borrowers. However, we observe that household income does not 
show the expected sign. One would expect wealthier families to be charged with a smaller ADIR, since they are supposed to be less likely to default on their mortgages (Diaz-Serrano, 2005). Possible explanations for this striking result could be that natives and immigrants receive disparate treatment in mortgage pricing regarding this variable, or that the effect of education overlaps the effect of income.

In Model 2, we use OLS to estimate again the determinants of the ADIR, but this time we include interactions between a dummy variable for immigrants and certain relevant variables: loan-to-value, mortgage term, mortgage amount, household income, education and labour contract. This model will allow to us disentangle whether lenders treat immigrant and native borrowers differently. We find that most of the covariates interacting with the dummy variable for immigrants are statistically significant at the 1 and 5\% levels. These results indicate that borrowers and natives do receive disparate treatment from lenders. For instance, ceteris paribus, immigrants are significantly more penalized than natives regarding loan-to-values and the term of the mortgage. Another interesting result is that when the income-immigrant interaction term is included, the sign of the estimated coefficient associated to income reverses to negative and becomes statistically significant at the $10 \%$ level for natives. In contrast, the income-immigrant interaction variable stays positive but becomes statistically significant at the $1 \%$ level. This result indicates that wealthier natives are charged with lower ADIR, while natives receive the opposite treatment. One should expect a negative effect for both groups. All the evidence provided in Model 2 suggests that natives and immigrants receive disparate treatment from lenders.

[Table 6, around here] 


\subsection{Oaxaca decompositions}

So far, the disparate mortgage pricing treatment that natives and immigrants receive from lenders observed in the previous subsection might indicate the potential existence of discrimination. To test this hypothesis, we carry out a Oaxaca-Blinder decomposition of the gap in the ADIR between natives and immigrants (equation 2). In order to disentangle the existence of racial patterns in this potential discriminatory treatment, we also carry out separate estimations of the decomposition across the different groups of immigrants: Latin Americans, Africans and Eastern Europeans.

The results of the decomposition analysis, which are reported in Table 7, are quite revealing. Discrimination, reported by the coefficient labelled as "unexplained", is significant for immigrants as a whole, as well as for each of the immigrant groups. Our estimates indicate that only one-third of the gap in the ADIR between immigrants and natives can be explained by market forces. The remaining two-thirds of the gap can be attributed to discrimination. This proportion holds constant for Latin American borrowers. For African and Eastern European borrowers, the level of discrimination is even more significant because up to three-quarters of the gap in the ADIR with respect to natives can be attributed to discriminatory treatment. The difference between discrimination coefficients in favour of Latin Americans and against Africans and Eastern Europeans could be explained by the better language skills of the Latin Americans, which would provide them with better bargaining skills.

[Table 7, around here] 
To conclude our analysis, we carry out some simulations of the effects of interest rates on expected mortgage repayments (Table 8). In simulation 1 we use estimated models in the Oaxaca-Blinder decomposition to simulate how the mortgage repayments of the average Spanish born borrower would increase if she were treated as an immigrant. Any increase in the mortgage reported in simulation 1 is the result of discriminatory treatment by lenders against immigrants. In contrast, in simulation 2 we estimate the changes in mortgage repayments if the average immigrant borrower were to receive the same treatment as the average native. Changes reported in simulation 2 come from differences between immigrants and natives regarding individual and loan characteristics. The difference between the amounts obtained in simulations 1 and 2 can be called the "price of discrimination". We base the simulations on an average mortgage of $200,000 €$ over a period of 35 years and a benchmark interest rate of $3.2 \%$.

In simulation 1, we find that the average Spanish borrower would pay $10,210 €$ more if her mortgage was priced using the same criteria that are used for Latin Americans. These amounts are 7,657€ and 9,494€ if lenders use the same criteria as are used for African and Eastern European borrowers. For simulation 2, we find that in the absence of discrimination, mortgage repayments would be reduced by $3033 €, 2628 €$ and $2274 €$ for Latin American, African and Eastern European borrowers, respectively. Finally, if we subtract the estimated amounts in simulation 2 from the estimated amounts in simulation 1, we find that the estimated price of discrimination is $7176 €$, $5029 €$ and $7220 €$ for Latin Americans, Africans and Eastern Europeans, respectively.

\section{Conclusions}


In this paper we test for the first time out of the U.S. whether immigrants are discriminated against the mortgage market. More specifically, we use data from Spain to test whether identical borrowers who differ only in their native or foreign-born status are charged with different average interest rates on their mortgages. We contribute to the existing literature in that this is the first analysis of this kind that has been done outside the US. Our estimates indicate that only one-third of the gap in the ADIR between immigrants and natives can be explained by market forces. The remaining twothirds of the gap can be attributed to discrimination. We estimate that immigrants may repay up to $7,200 €$ more than natives (excluding commissions) due to discriminatory treatment by lenders. This is undoubtedly a very high price of discrimination. Our results are in line with studies that find evidence of discrimination once relevant variables have been controlled for (Boehm and Schlottmann (2007), Courchane and Nickerson (1997), Black et al (2003), and Boehm and Schlottmann (2007)).

We recognize that an empirical model on mortgage pricing which controlled for the probability of acceptance would provide a more suitable framework because it would prevent potential selection bias. However, we have been unable to create such a model because our data is based on loans that have already been granted, and data that allows for selectivity correction is not generally available. On the whole, the relevant variables that determine the probability of rejection are the same as those that determine the price of a mortgage; therefore, controlling for these variables in the price equation dispels the potential selection bias. Consequently, we believe that if there is any selection bias, it is fairly modest. 
One may also fear the devastating effect of omitted variable bias. However, we have controlled for a large set of relevant variables regarding supply and demand factors; therefore, we think that this is unlikely to be a problem in our estimates.

The policy implications of our results are clear. Once evidence of discrimination in lending markets appears, Spanish legislators must consider passing more specific laws to protect minorities from unfair practices in lending markets, as has been the case in the US. However, we also recognize that more empirical evidence is needed before such policies can be implemented. 


\section{References}

H. Black, R. Schweitzer and L. Mandell, "Discrimination in Mortgage Lending," American Economic Review 68 (1978): 186-91;

H. Black and R. Schweitzer, "A Canonical Analysis of Mortgage Lending Terms," Urban Studies 22 (1985): 13-9.

Black, H.A., Boehm, T.P., DeGennaro, R.P. (2001): “Overages, mortgage pricing and race”, International Journal of Finance 13, Issue 4, 2057-2073.

Black, H., Boehm,T. and DeGennaro, R. (2003): "Is there discrimination in mortgage pricing? he case of overages", Journal of Banking \& Finance 27 (2003) 11391165.

Boehm, P. and Schlotmann, A. (2007): "Mortgage Pricing Differentials Across Hispanic, Black, and White Households", A Journal of Policy Development and Research 9, issue 2, 93-136.

G. Canner, S. Gabriel, and J. Wooley, "Race, Default Risk and Mortgage Lending," Southern Economic Journal 58 (1991): 249-62.

G. Canner and D. Smith, "Home Mortgage Disclosure Act: Expanded Data on Residential Lending," Federal Reserve Bulletin 77 (1991): 859-881;

G. Canner and S. Gabriel, "Market Segmentation and Lender Specialization in the Primary and Secondary Mortgage Markets," Housing Policy Debate 3 (1992): 241-329.

Carr, James H. and Isaac Megbolugbe. (1993). "The Federal Reserve Bank of Boston Study on Mortgage Lending Revisited." Journal of Housing Research 4(2), 277313. 
Cloud, Cathy; Galster, George; Review of Black Political Economy, Summer 1993, v. 22 , iss. 1 , pp. $101-20$

Courchane, M., Nickerson, D., 1997. Discrimination resulting from overage practices. Journal of Financial Services Research 11, 133-152.

Courchane, M. (2007): “The Pricing of Home Mortgage Loans to Minority Borrowers: How Much of the APR Differential Can We Explain?", Journal of Real State Research 29, Issue 4, 399-440.

B. Dedman, "The Color of Money," The Atlanta Journal Constitution, May 14, 1988.

Diaz-Serrano, L. (2005), "Income Volatility and Residential Mortgage Delinquency across the EU", Journal of Housing Economics 14, 153-177.

G. Galster, A Statistical Perspective on Illegal Discrimination in Lending (Washington, DC: American Bankers Association, 1991)

G. Galster, "A Theoretical Framework for Econometrically Analyzing Mortgage Lending Activity in Census Tracts," Urban Affairs Quarterly 28 (1992): 146155

G. Galster, "Research on Discrimination in Housing and Mortgage Markets: Assessment and Future Directions," Housing Policy Debate 3 (1992): 639-683.

Hunter, W. Curt, and M.B. Walker. (1996). "The Cultural Affinity Hypothesis and Mortgage Lending Decisions." Journal of Real Estate Finance and Economics 13(1), 57-50.

Lacour-Little (1999): "Discrimination in Mortgage Lending: A Critical Review of the Literature", Journal of Real Estate Literature, 7: 15-49.

G. Maddala and R. Trost, "On Measuring Discrimination in Loan Markets," Housing Finance Review 1 (1982): 245-68. 
Alicia Munnell, Lynn Browne, James McEneaney, and Geoffrey Tootell, Mortgage Lending in Boston: Interpreting HMDA Data Federal Reserve Bank of Boston Working Paper 92-7, (1992).

Federal Reserve Governor John LaWare, quoted by Paul Wiseman, "Bankers Grumpy Despite Strong Profits," USA Today, (Oct. 19, 1992), p. 6B.

Rachlis, Mitchell, and Anthony Yezer. (1993). "Serious Flaws in Statistical Tests for Discrimination in Mortgage Markets." Journal of Housing Research 4(2), 315336.

A. Shlay, "Financing Community: Methods for Assessing Residential Credit Disparities, Market Barriers and Institutional Reinvestment Performance in the Metropolis," Journal of Urban Affairs, 11 (1989): 201-233;

Yezer, Anthony M., Robert F. Phillips, and Robert P. Trost. (1994). "Bias in Estimates of Discrimination and Default in Mortgage Lending: The Effects of Simultaneity and Self Selection." Journal of Real Estate Financeand Economists 9(3), 197216. 
Table 1: Variable definitions

\begin{tabular}{|c|c|}
\hline Variable & Description \\
\hline Annual differential interest rate & Differential applied over the benchmark interest rate (euribor ${ }^{11}$ ). \\
\hline Opening commission & $\begin{array}{l}\text { Commission (\%) levied on the borrower by the bank for setting up the } \\
\text { mortgage }\end{array}$ \\
\hline Partial cancellation commission & Penalty paid in the event of early repayment of part of the loan \\
\hline Total cancellation commission & Penalty paid in the event of early repayment of the whole loan \\
\hline Loan-to-value & Loan amount against the value of the dwelling \\
\hline Age & Age (in years) of the principal holder of the mortgage. \\
\hline Income & Net monthly household income \\
\hline Mortgage & Loan amount \\
\hline Holders & Number of individuals holding the mortgage \\
\hline \multirow{2}{*}{$\underline{\text { Type of job }}$} & Dummies for the borrower's type of job \\
\hline & Administrative officer, Manager, White collar, Blue collar, other \\
\hline \multirow[t]{2}{*}{ Education } & Dummies for the borrower's level of education \\
\hline & Primary or lower, Secondary, University \\
\hline Type of contract & Type of contract of the borrower \\
\hline Indefinite & Dummy variable: $1=$ Indefinite contract; $0=$ Other. \\
\hline Fixed discontinuous & Dummy variable: $1=$ Fixed discontinuous contract; $0=$ Other. \\
\hline Without contract & Dummy variable: $1=$ without contract; $0=$ Other. \\
\hline Temporary & Dummy variable: $1=$ temporary contract; $0=$ Other. \\
\hline Work and service & Dummy variable: $1=$ work and service contract; $0=$ Other. \\
\hline$\underline{\text { Marital status }}$ & Marital status of the borrower \\
\hline Married & Dummy variable: $1=$ married; $0=$ Other. \\
\hline Living with a partner & Dummy variable: $1=$ living with a partner; $0=$ Other. \\
\hline Separated & Dummy variable: $1=$ separated; $0=$ Other. \\
\hline Single & Dummy variable: $1=$ single; $0=$ Other. \\
\hline Widower & Dummy variable: $1=$ widowed; $0=$ Other. \\
\hline Term & Loan duration in years \\
\hline Nationality & Nationality of the borrower \\
\hline Spanish & Dummy variable: $1=$ Spanish; $0=$ Other. \\
\hline Latin American & Dummy variable: $1=$ Latin American; $0=$ Other. \\
\hline African & Dummy variable: $1=$ African; $0=$ Other. \\
\hline Asian \& Oceanian & Dummy variable: $1=$ Asian or Oceanian; $0=$ Other. \\
\hline Rich countries & Dummy variable: $1=$ From rich countries; $0=$ Other. \\
\hline East European & Dummy variable: $1=$ East European; $0=$ Other. \\
\hline
\end{tabular}

${ }^{11}$ Euribor is the reference index for $99 \%$ of Spanish mortgages. 
Table 2: Descriptive statistics

\begin{tabular}{|c|c|c|c|c|c|c|c|c|}
\hline & \multicolumn{2}{|c|}{ Spanish } & \multicolumn{2}{|c|}{ Latin American } & \multicolumn{2}{|c|}{ African } & \multicolumn{2}{|c|}{ Easter Europe } \\
\hline & Mean & Std. Dev. & Mean & Std. Dev. & Mean & Std. Dev. & Mean & Std. Dev. \\
\hline Differential interest rate & 0.837 & 0.348 & 1.045 & 0.450 & 1.019 & 0.467 & 1.057 & 0.399 \\
\hline Opening commission & 1.044 & 0.448 & 1.083 & 0.396 & 1.154 & 0.386 & 1.046 & 0.418 \\
\hline Debt to income & 0.561 & 0.272 & 0.753 & 0.282 & 0.616 & 0.267 & 0.662 & 0.266 \\
\hline Loan to value & 81.516 & 16.173 & 90.706 & 11.546 & 87.592 & 12.537 & 89.467 & 11.656 \\
\hline Age & 33.94 & 10.35 & 34.68 & 8.12 & 33.92 & 7.27 & 34.23 & 7.64 \\
\hline Income & $1,447.39$ & 773.98 & $1,398.36$ & 688.36 & $1,331.64$ & 588.84 & $1,454.89$ & 766.62 \\
\hline Mortgage & 169,941 & 146,279 & 206,865 & 65,195 & 159,932 & 61,271 & 185,506 & 67,490 \\
\hline Holders & 1.794 & 0.644 & 2.144 & 0.715 & 1.770 & 0.722 & 1.917 & 0.675 \\
\hline Clerical & 0.032 & 0.175 & 0.011 & 0.105 & 0.004 & 0.060 & 0.011 & 0.104 \\
\hline Manager & 0.040 & 0.197 & 0.016 & 0.126 & 0.009 & 0.093 & 0.014 & 0.118 \\
\hline Qualified & 0.455 & 0.498 & 0.255 & 0.436 & 0.243 & 0.429 & 0.329 & 0.470 \\
\hline Not qualified & 0.337 & 0.473 & 0.574 & 0.495 & 0.551 & 0.498 & 0.549 & 0.498 \\
\hline Other & 0.136 & 0.343 & 0.143 & 0.350 & 0.194 & 0.395 & 0.097 & 0.297 \\
\hline Primary & 0.488 & 0.500 & 0.793 & 0.405 & 0.875 & 0.331 & 0.787 & 0.410 \\
\hline Secondary & 0.378 & 0.485 & 0.179 & 0.384 & 0.108 & 0.310 & 0.187 & 0.390 \\
\hline University & 0.134 & 0.341 & 0.028 & 0.164 & 0.017 & 0.130 & 0.026 & 0.159 \\
\hline Indefinite & 0.573 & 0.495 & 0.525 & 0.499 & 0.377 & 0.485 & 0.514 & 0.500 \\
\hline Fixed discontinuous & 0.023 & 0.150 & 0.030 & 0.169 & 0.037 & 0.190 & 0.031 & 0.174 \\
\hline Temporary & 0.317 & 0.465 & 0.418 & 0.493 & 0.564 & 0.496 & 0.418 & 0.493 \\
\hline Without contract & 0.003 & 0.058 & 0.002 & 0.040 & 0.006 & 0.076 & 0.000 & 0.000 \\
\hline Work and service & 0.084 & 0.277 & 0.025 & 0.158 & 0.015 & 0.122 & 0.037 & 0.188 \\
\hline Married & 0.341 & 0.474 & 0.417 & 0.493 & 0.295 & 0.456 & 0.485 & 0.500 \\
\hline Living with a partner & 0.005 & 0.071 & 0.006 & 0.077 & 0.002 & 0.046 & 0.003 & 0.057 \\
\hline Separated & 0.073 & 0.260 & 0.017 & 0.129 & 0.010 & 0.100 & 0.011 & 0.104 \\
\hline Single & 0.568 & 0.495 & 0.557 & 0.497 & 0.691 & 0.462 & 0.498 & 0.500 \\
\hline Widower & 0.013 & 0.115 & 0.003 & 0.057 & 0.001 & 0.038 & 0.003 & 0.057 \\
\hline Term & 33.662 & 6.440 & 34.092 & 5.145 & 34.609 & 4.939 & 33.791 & 5.239 \\
\hline Simple size & \multicolumn{2}{|c|}{12,641} & \multicolumn{2}{|c|}{3,569} & \multicolumn{2}{|c|}{1,347} & \multicolumn{2}{|c|}{898} \\
\hline
\end{tabular}


Table 3: Test of mean differences in the ADIR according to birthplace

\begin{tabular}{llll}
\hline & Mean & Diff. & t-stat \\
\hline Spanish & 0.837 & & \\
Latin American & 1.045 & 0.208 & 22.28 \\
African & 1.019 & 0.182 & 14.04 \\
East European & 1.057 & 0.220 & 14.07 \\
Non Spanish born & 1.041 & 0.204 & 39.76 \\
\hline
\end{tabular}


Table 4: Tests of mean differences in the ADIR between immigrants and Spanish born individuals in terms of selected cities.

\begin{tabular}{lccccc}
\hline & $\mathbf{N}$ & Spanish & Immigrants & Diff & t-value \\
\hline Alicante & 466 & 0.905 & 1.074 & 0.169 & 5.55 \\
Barcelona & 5,008 & 0.628 & 0.796 & 0.168 & 5.96 \\
Bilbao & 204 & 0.767 & 1.001 & 0.234 & 4.04 \\
Cordoba & 261 & 0.882 & 0.993 & 0.111 & 1.73 \\
Huelva & 2,324 & 0.974 & 1.349 & 0.364 & 6.02 \\
Madrid & 7635 & 0.860 & 1.111 & 0.251 & 29.63 \\
Malaga & 529 & 0.879 & 1.086 & 0.207 & 5.49 \\
Seville & 848 & 0.796 & 0.882 & 0.086 & 2.42 \\
Valencia & 1,176 & 0.933 & 1.135 & 0.202 & 9.53 \\
Valladolid & 298 & 0.850 & 1.332 & 0.482 & 10.70 \\
Zaragoza & 986 & 0.825 & 1.049 & 0.224 & 8.73 \\
\hline
\end{tabular}


Table 5: Tests of mean differences in the ADIR between immigrants and Spanish born individuals in terms of selected banks.

\begin{tabular}{|c|c|c|c|c|c|c|c|c|}
\hline & \multicolumn{3}{|c|}{ Spanish born } & \multicolumn{3}{|c|}{ Immigrants } & \multirow[t]{2}{*}{ Diff. } & \multirow[t]{2}{*}{ t-value } \\
\hline & $N$ & Mean & s.d. & $N$ & Mean & s.d. & & \\
\hline Bank A & 3,102 & 0.986 & 0.107 & 648 & 1.208 & 0.288 & 0.222 & 19.35 \\
\hline Bank B & 367 & 0.907 & 0.344 & 101 & 0.947 & 0.377 & 0.04 & 0.96 \\
\hline Bank C & 3,198 & 0.548 & 0.334 & 1,105 & 1.125 & 0.598 & 0.577 & 30.47 \\
\hline Bank D & 115 & 0.727 & 0.238 & 55 & 0.914 & 0.339 & 0.187 & 3.68 \\
\hline Bank E & 8,097 & 0.711 & 0.332 & 1,113 & 1.048 & 0.306 & 0.337 & 34.09 \\
\hline Bank F & 133 & 0.869 & 0.251 & 228 & 0.981 & 0.267 & 0.112 & 3.99 \\
\hline Bank G & 102 & 0.57 & 0.449 & 1,013 & 0.654 & 0.749 & 0.084 & 1.67 \\
\hline Bank H & 2,742 & 0.887 & 0.168 & 2,377 & 1.123 & 0.386 & 0.236 & 27.63 \\
\hline Bank I & 221 & 0.853 & 0.55 & 114 & 0.899 & 0.6 & 0.046 & 0.68 \\
\hline Bank J & 2576 & 0.961 & 0.119 & 1,165 & 0.971 & 0.292 & 0.01 & 1.13 \\
\hline Bank K & 122 & 0.99 & 0.415 & 231 & 1.319 & 0.289 & 0.329 & 7.81 \\
\hline Bank L & 148 & 1.073 & 0.5 & 145 & 1.496 & 0.513 & 0.423 & 7.15 \\
\hline Bank M & 178 & 0.877 & 0.193 & 30 & 1.328 & 0.469 & 0.451 & 5.19 \\
\hline Bank N & 148 & 1.016 & 0.263 & 118 & 1.158 & 0.211 & 0.142 & 4.89 \\
\hline
\end{tabular}


Table 6: OLS regressions on the Average Differential Interest Rate (ADIR)

\begin{tabular}{|c|c|c|c|c|}
\hline & \multicolumn{2}{|c|}{ Model 1} & \multicolumn{2}{|c|}{ Model 2} \\
\hline & Coef. & t-val. & Coef. & t-val. \\
\hline Constant & 0.224 & 0.78 & 0.361 & 1.26 \\
\hline Loan to value & 0.003 & 12.50 & 0.002 & 6.64 \\
\hline$x$ Immigrant & & & 0.003 & 6.23 \\
\hline Term & 0.002 & 3.79 & 0.001 & 1.32 \\
\hline$x$ Immigrant & & & 0.003 & 2.54 \\
\hline Age & 0.004 & 2.33 & 0.002 & 5.32 \\
\hline Holders & 0.043 & 10.15 & 0.045 & 10.57 \\
\hline Mortgage & 0.027 & 3.47 & 0.059 & 6.35 \\
\hline$x$ Immigrant & & & -0.070 & -5.59 \\
\hline $\begin{array}{l}\text { Income } \\
\qquad x \text { Immigrant }\end{array}$ & 0.007 & 1.57 & $\begin{array}{r}-0.013 \\
0.033\end{array}$ & $\begin{array}{r}-1.96 \\
3.99\end{array}$ \\
\hline \multicolumn{5}{|l|}{ Type of job } \\
\hline Manager & -0.022 & -0.84 & -0.021 & -0.82 \\
\hline Qualified & -0.011 & -0.53 & -0.014 & -0.72 \\
\hline Not qualified & -0.026 & -1.28 & -0.027 & -1.35 \\
\hline Other & -0.016 & -0.77 & -0.024 & -1.15 \\
\hline \multicolumn{5}{|l|}{ Education } \\
\hline$\overline{\text { Secondary }}$ & -0.082 & -13.02 & -0.097 & -12.24 \\
\hline x Immigrant & & & 0.048 & 3.78 \\
\hline $\begin{array}{l}\text { University } \\
\quad x \text { Immigrant }\end{array}$ & -0.123 & -10.82 & $\begin{array}{r}-0.136 \\
0.042\end{array}$ & $\begin{array}{r}-10.54 \\
1.60\end{array}$ \\
\hline \multicolumn{5}{|l|}{ Type of contract } \\
\hline $\begin{array}{c}\text { Fixed discontinuous } \\
x \text { Immigrant }\end{array}$ & 0.052 & 3.15 & $\begin{array}{r}0.064 \\
-0.022\end{array}$ & $\begin{array}{r}2.36 \\
-0.64\end{array}$ \\
\hline $\begin{array}{l}\text { Without contract } \\
x \text { Immigrant }\end{array}$ & 0.063 & 10.99 & $\begin{array}{r}0.075 \\
-0.018\end{array}$ & $\begin{array}{r}9.06 \\
-1.61\end{array}$ \\
\hline $\begin{array}{l}\text { Temporary } \\
x \text { Immigrant }\end{array}$ & 0.113 & 2.08 & $\begin{array}{r}0.161 \\
-0.099\end{array}$ & $\begin{array}{r}2.09 \\
-0.92\end{array}$ \\
\hline $\begin{array}{l}\text { Work and service } \\
x \text { Immigrant }\end{array}$ & 0.037 & 2.67 & $\begin{array}{r}0.040 \\
-0.022\end{array}$ & $\begin{array}{r}2.42 \\
-0.75\end{array}$ \\
\hline Marital status & & & & \\
\hline Living with a partner & -0.046 & -1.16 & -0.048 & -1.20 \\
\hline Separated & 0.056 & 3.88 & 0.056 & 3.88 \\
\hline Single & 0.015 & 2.48 & 0.017 & 2.73 \\
\hline Widower & 0.056 & 1.75 & 0.042 & 1.33 \\
\hline \multicolumn{5}{|l|}{ Birthplace } \\
\hline Immigrants & & & -0.061 & -0.74 \\
\hline Latin America & 0.146 & 21.00 & & \\
\hline Africa & 0.136 & 14.56 & & \\
\hline Eastern Europe & 0.140 & 13.00 & & \\
\hline $\mathrm{N}$ & 18710 & & 18710 & \\
\hline $\mathrm{R}^{2}$ & 0.53 & & 0.54 & \\
\hline
\end{tabular}


Table 7: Oaxaca-Blinder decomposition of ADIR differentials

Eastern

\begin{tabular}{|c|c|c|c|c|c|c|c|c|}
\hline & \multicolumn{2}{|c|}{ Immigrants } & \multicolumn{2}{|c|}{ Latin American } & \multicolumn{2}{|c|}{ African } & \multicolumn{2}{|c|}{ European } \\
\hline & Coef. & $\overline{t \text {-stat }}$ & Coef. & $\overline{t \text {-stat }}$ & Coef. & $\overline{t \text {-stat }}$ & Coef. & $t$-stat \\
\hline Gap & 0.2170 & 32.45 & 0.2213 & 27.46 & 0.1946 & 15.08 & 0.2336 & 14.83 \\
\hline \multirow[t]{2}{*}{ Explained } & 0.0740 & 10.54 & 0.0753 & 9.87 & 0.0433 & 4.09 & 0.0620 & 5.90 \\
\hline & $34.1 \%$ & & $34.1 \%$ & & $22.3 \%$ & & $26.5 \%$ & \\
\hline \multirow[t]{2}{*}{ Unexplained } & 0.1430 & 18.06 & 0.1460 & 16.05 & 0.1513 & 11.34 & 0.1716 & 10.68 \\
\hline & $65.9 \%$ & & $65.9 \%$ & & $77.7 \%$ & & $73.5 \%$ & \\
\hline
\end{tabular}


Table 8: Simulations of the expected increase in life-time mortgage repayments for immigrants due to discrimination

\begin{tabular}{lcccc}
\hline Simulation 1 & $\begin{array}{c}\text { Latin } \\
\text { American }\end{array}$ & African & East European & Spanish \\
\hline Estimated ADIR & 1.024 & 0.974 & 1.010 & 0.823 \\
Estimated differential ADIR & 0.201 & 0.151 & 0.187 & \\
Estimated differential amount $(€)$ & $10,210.00$ & $7,657.71$ & $9,494.53$ & \\
\hline & & & & \\
\hline Simulation 2 & Latin & & & \\
\hline Estimated ADIR & American & African & East European & Spanish \\
Estimated differential ADIR & 0.883 & 0.875 & 0.868 & 0.823 \\
Estimated differential amount $(€)$ & $3,033.72$ & $2,628.53$ & $2,274.17$ & \\
\hline
\end{tabular}

